\title{
Increasing social-ecological resilience within small-scale agriculture in conflict-affected Guatemala
}

\author{
$\underline{\text { Jon Hellin }}^{1,2}$, Blake D. Ratner $^{3,4}$, Ruth Meinzen-Dick $^{5}$ and Santiago Lopez-Ridaura $^{1}$
}

\begin{abstract}
Climate change scenarios suggest largely detrimental impacts on agricultural production from a deterioration of renewable natural resources. Over the last 15 years, a new field of research has focused on the interactions between climate and conflict risk, particularly as it relates to competition over natural resources and livelihoods. Within this field, there has been less attention to the potential for resource competition to be managed in ways that yield greater cooperation, local adaptation capacity, social-ecological resilience, and conflict mitigation or prevention. The challenge of increasing social-ecological resilience in small-scale agriculture is particularly acute in the socioeconomically and agroecologically marginalized Western Highlands of Guatemala. Not only is climate change a threat to agriculture in this region, but adaptation strategies are challenged by the context of a society torn apart by decades of violent conflict. Indeed, the largely indigenous population in the Western Highlands has suffered widespread discrimination for centuries. The armed conflict has left a legacy of a deeply divided society, with communities often suspicious of outsider interventions and in many cases with neighbors pitted against each other. We use the example of the Buena Milpa agricultural development project to demonstrate how grassroots approaches to collective action, conflict prevention, and social-ecological resilience, linking local stakeholder dynamics to the broader institutional and governance context, can bear fruit amidst postconflict development challenges. Examples of microwatershed management and conservation of local maize varieties illustrate opportunities to foster community-level climate adaptation strategies within small-scale farming systems even in deeply divided societies.
\end{abstract}

Key Words: agriculture; climate change; collective action; conflict; Guatemala; resilience

\section{INTRODUCTION}

There is increasing concern about the impacts of climate change on agricultural production and productivity (Vermeulen et al. 2013). Changes in precipitation are a concern, as are increases in temperature. Climate change will increase water scarcity in the coming decades with detrimental impacts on agriculture (Gleditsch et al. 2006, Brown and Funk 2008, Lobell et al. 2008, Hanjra and Qureshi 2010). Climate change is, hence, likely to compromise the food security of many farmers. Agricultural research can contribute to climate change adaptation and mitigation strategies designed to enhance farmers' food security. The focus is on ensuring that farmers have access to technologies and knowledge that will enable them to continue growing crops in the face of increased climate risk. To date, much attention has focused on the development of agricultural technologies such as drought tolerant germplasm, fertilizer, conservation agriculture, and improved postharvest storage, linked to the promotion of wider land use and governance changes (Brown and Funk 2008). However, farmer adoption of these technologies has often been disappointing, largely because less attention has been paid to the social dynamics of technology adoption and adaptation (Hellin and López-Ridaura 2016).

There are also concerns that climate stress is exacerbating disputes over land, water, forests, and fisheries, and that this can exacerbate other sources of social conflict, even if locally specific and typically nonviolent in nature. The argument is that climate change undermines human security by reducing people's access to natural resources that are important to sustain their livelihoods (Barnett and Adger 2007). Climate change is also likely to undermine the capacity of states to provide the opportunities and services that enable people to sustain their livelihoods, and which help to maintain and build peace. In some cases, this may fuel land grabs. In a range of circumstances, these direct and indirect impacts of climate change on human security and the state may increase the risk of social breakdown and conflict (Hendrix and Glaser 2007).

The focus on the relationship between natural resources and conflict (supported by significant scientific and public attention) should be balanced with attention to the potential for management of natural resources to also be a focus of cooperation, helping build resilient institutions that can moderate and reduce the disruptive impacts of conflict. This raises the question of whether and how resource competition can be transformed to strengthen social-ecological resilience, enhance local adaptation capacity and mitigate conflict (Institute of Development Studies 2010). Yet, there is relatively little documentation regarding the positive role of collective natural resource management efforts to reduce conflict.

The importance of collective action in adaptation is well recognized. Scheffran et al. (2012:870) ask whether "human development, resilience, and adaptive capacity can compensate for increasing exposure and sensitivity to climate change." Adger (2003:387) emphasizes that "adaptation is a dynamic social process: the ability of societies to adapt is determined, in part, by the ability to act collectively." Collective action comprises concerted group effort to achieve a shared goal (Ratner et al. 2013). It is something that group members can carry out directly or that organizations can pursue on behalf of their members.

In this vein flows a large body of work on collective action and natural resource management, much of it influenced by the Nobel Laureate Elinor Ostrom. Building on the institutional analysis and development (IAD) model (Ostrom 2005), and incorporating principles from the sustainable livelihoods approach and resilience theory, Ratner et al. (2013) present an analytical framework designed to assess the role of collective action in

${ }^{1}$ International Maize and Wheat Improvement Center (CIMMYT), ${ }^{2}$ Current affiliation International Rice Research Institute (IRRI), ${ }^{3}$ WorldFish, CGIAR, ${ }^{4}$ Collaborating for Resilience, ${ }^{5}$ International Food Policy Research Institute (IFPRI) 
natural resource conflict and cooperation (see below). The framework is applicable across multiple scales of analysis, linking local stakeholder dynamics to the broader institutional and governance context. Later work by Ratner et al. (2017) also shows how understanding the factors that influence collective action can yield insights about the policies and strategies needed to promote equitable outcomes. The framework informed the work in Guatemala reported in this paper.

A premise of the framework is that the social-ecological and governance context influences the scope for collective action in natural resource management. It follows that the character of natural resource management institutions affects incentives in favor of conflict or cooperation, and the outcomes of these interactions influence future conflict risk, livelihoods, and resource sustainability.

In developing countries where access to and use of renewable, common-pool resources essential to rural livelihoods is highly contested, improving cooperation in their management is increasingly seen as an important element in strategies for peacebuilding, conflict prevention, and longer-term social-ecological resilience (Ratner et al. 2013:184).

Resilience classically refers to the capacity of a social-ecological system to absorb disturbances and reorganize while undergoing change to retain essentially the same function, structure, identity, and feedbacks (Walker et al. 2004). This includes sustaining the productivity of natural resource systems and the adaptive capacity of social institutions to manage change in ways that do not lead to social breakdown and conflict. There is, however, a need to capture the subtle differences in emphasis between the social and ecological dimensions of resilience in the context of small-scale cropping systems, where there is also a strong imperative of human development. This echoes the distinction that Barrett and Constas (2014) make between ecological and development resilience. In the case of the former, the emphasis is on "persistence and recovery in the face of change and unpredictability," while the latter "concerns individual agents with basic rights as well as aspirations for improved living conditions, that necessitates differentiation from and adaptation of preexisting, systems-oriented uses of the resilience concept in fields like ecology" (Barrett and Constas 2014:14625).

In the context of climate risk and collective action in poor rural communities, social resilience requires improvements in people's well-being and reduction in vulnerability (Adger et al. 2013). Hence, social-ecological resistance not only requires the ecological characteristics of persistence and recovery but also the conditions for households to move from one asset threshold and livelihood pathway to another.

We use case study material from the Buena Milpa project to examine this potential for livelihood transformation, analyzed through the lens of a conceptual framework on resource conflict, collective action, and social-ecological resilience. This responds to what Fisher, Bavinck, and Amsalu (unpublished manuscript) argue is the need for nuanced understandings of conflict and cooperation, as embedded within specific contexts, and with the influence of wider processes of power and accumulation framed by particular temporal and spatial dynamics. The Western
Highlands of Guatemala is a particularly challenging place to work following the three-decades-long violent conflict that ended in 1996 but where many of the causes of conflict still exist, particularly inequitable land distribution, ethnic discrimination, entrenched rural poverty, and gender-based violence. The country's long-standing social divisions, exacerbated by prolonged violent conflict, make this case particularly important in the study of pathways to social-ecological resilience.

\section{CONTEXT OF THE BUENA MILPA PROJECT IN THE WESTERN HIGHLANDS, GUATEMALA}

Collective action in natural resource conflict and cooperation We draw upon the learning of Buena Milpa, a research-fordevelopment project in the Western Highlands of Guatemala supported by the United States Agency for International Development (USAID) and implemented by the International Maize and Wheat Improvement Center (CIMMYT). Buena Milpa began in 2014 and the first author has been instrumental in the design and implementation of the project. Buena Milpa has adopted an innovative way to enhance farmers' socialecological resilience in the context of climate change adaptation. The main objectives of the project are to contribute to the reduction of poverty, food insecurity, and malnutrition, while increasing sustainability and resilience of maize-based farming systems. To achieve this it seeks to decrease environmental degradation, improve the livelihoods of small-scale and resourcepoor farmers, strengthen research and extension activities, and establish links with strategic partners that include NGOs, public agencies, and extension agents.

Buena Milpa's approach has been influenced by the aforementioned framework developed by Ratner et al. (2013). The framework has four main elements: context, collective action institutions, action arena, and outcomes (see Fig. 1). One purpose of the framework is to elucidate how interventions can shift the incentives toward cooperative and equitable management of resource competition and reduce the likelihood of an escalation of social conflict.

The context comprises characteristics of the resources and resource users (including livelihood assets and vulnerabilities), as well as governance arrangements in terms of distribution of power, representation, and mechanisms of accountability. Meanwhile, collective action institutions, such as farmer cooperatives, provide rules and norms to guide members' behavior with respect to resource access, use, and benefits. Stakeholders interact within socially defined action arenas that can exist at multiple scales, and may be both formal and informal, e.g., the activities of a development organization and/or farmer organization.

Ratner et al. (2017) identify three distinct domains for intervention (see Fig. 1). First, and as applied to the agricultural development context, there are governance and policy interventions that promote collective action. Several actors can play a key role in improving governance. Governments are often responsible for policies that address agriculture. Development agencies often support these reform efforts through financial and technical assistance. Meanwhile, civil society actors are often engaged in advocacy for institutional and policy change. All these actors can contribute to improved governance in ways that 
Fig. 1. Framework for analysis of conflict and cooperation in natural resources management, showing three windows for intervention. Source: Ratner et al. 2017.

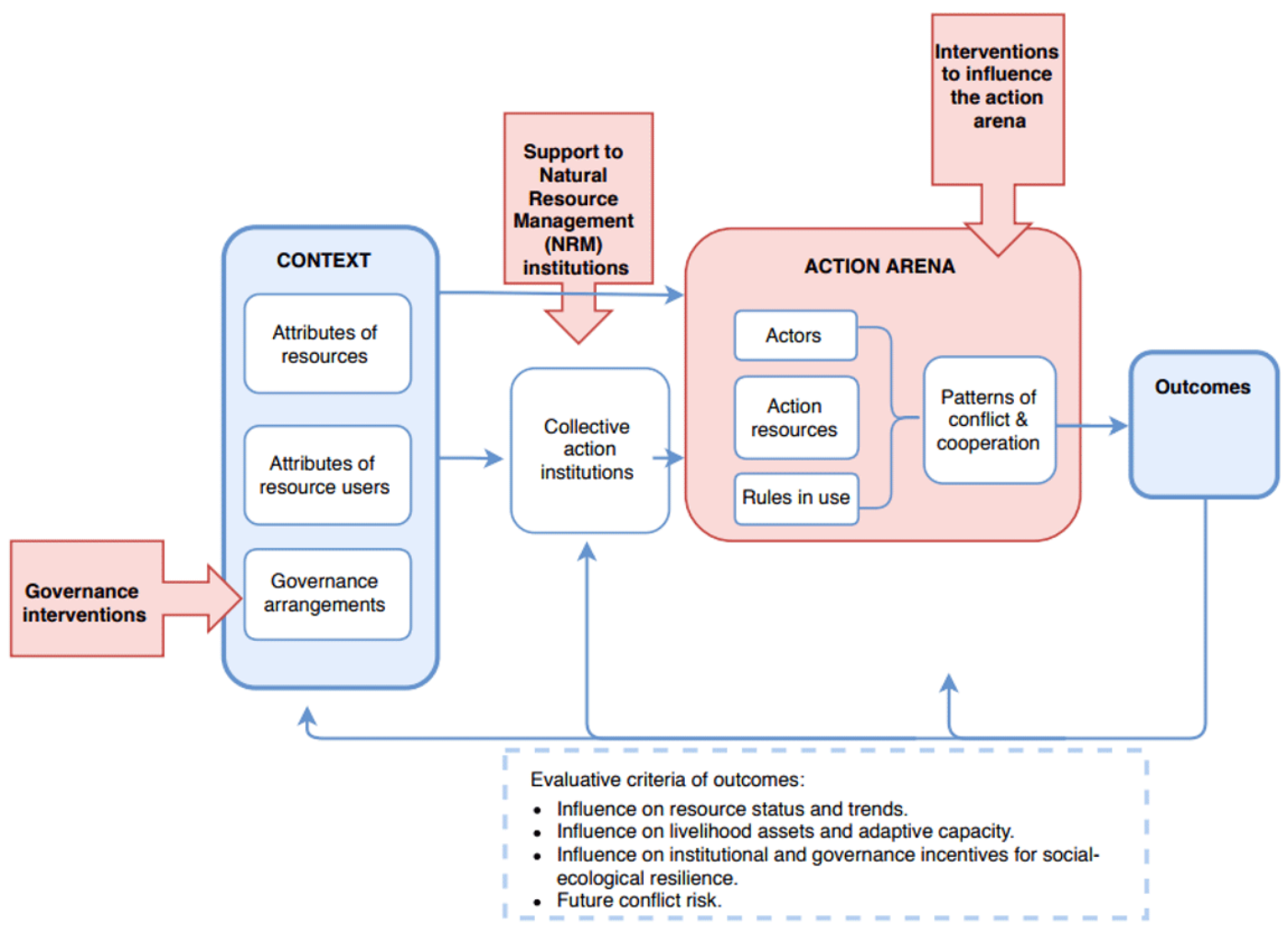

promote collective action for a more sustainable agriculture. Second, support can be provided to natural resource management institutions to increase their capacity for collective action to respond to resource competition. This can help prevent the escalation of conflict over natural resources as well as facilitating recovery in postconflict situations of which Guatemala is a good example. Third, there are measures to affect the action arena in ways that mitigate conflict over natural resources.

In the case of the action arena, it is very important to factor in the characteristics of the actors, their resources, and the institutional constraints and opportunities that determine the extent to which collective action can emerge and become sustainable. There are many organizations working directly with stakeholders to strengthen collective action in the agriculture sector. A key element is building trust and among stakeholders (Ratner et al. 2013). Buena Milpa has placed much emphasis on interventions to influence the action arena in ways that (re)build trust among diverse actors. This is very important in the Western Highlands because it is a region scarred by armed conflict and one where many of the causes of the three-decade-long conflict still exist.

After providing details on the context of the Western Highlands, we use three examples from the work that Buena Milpa has carried out (see Fig. 2). These examples cover natural resource management in two different microwatersheds and maize seed management. Together they illustrate the importance of (i) governance interventions; (ii) support to collective action institutions; and, (iii) interventions to influence the action arena in order to bring about favorable outcomes in terms of increased social-ecological resilience.

\section{The context}

Guatemala has the highest level of child undernutrition in the western hemisphere and the fourth highest in the world (WFP 2014). The International Fund for Agricultural Development (2011) has calculated that approximately $70 \%$ of the impoverished population lives in rural areas, where poverty is highly concentrated among indigenous groups. These indigenous groups comprise $38 \%$ of the total population and live mainly in the Western Highlands. Lovell (1983) reports on the historic exploitation of indigenous groups in parts of the Western Highlands, including the system of encomienda in which wealthy individuals (often Spaniards or their descendants) received the tribute and labor of a designated number of indigenous people. Such exploitation formed the basis of the colonial Spanish economy and continued after Guatemala gained independence in 1821, giving long historical roots to contemporary inequalities. Over 70 years ago, Higbee (1947) also noted the sharp economic, social, and political divisions between indigenous peoples and mestizos. Historic and ongoing discrimination has led to structural exclusion, social inequality, and violence (Steinberg and Taylor 2008). With significant gender inequality across Guatemala, including gender-based violence (Democracy International 2015), for indigenous women in the Western Highlands, inequality and exclusion is particularly acute. 
Fig. 2. Western Highlands, Guatemala. Cartography: Santiago López-Ridaura and Luis Barba.

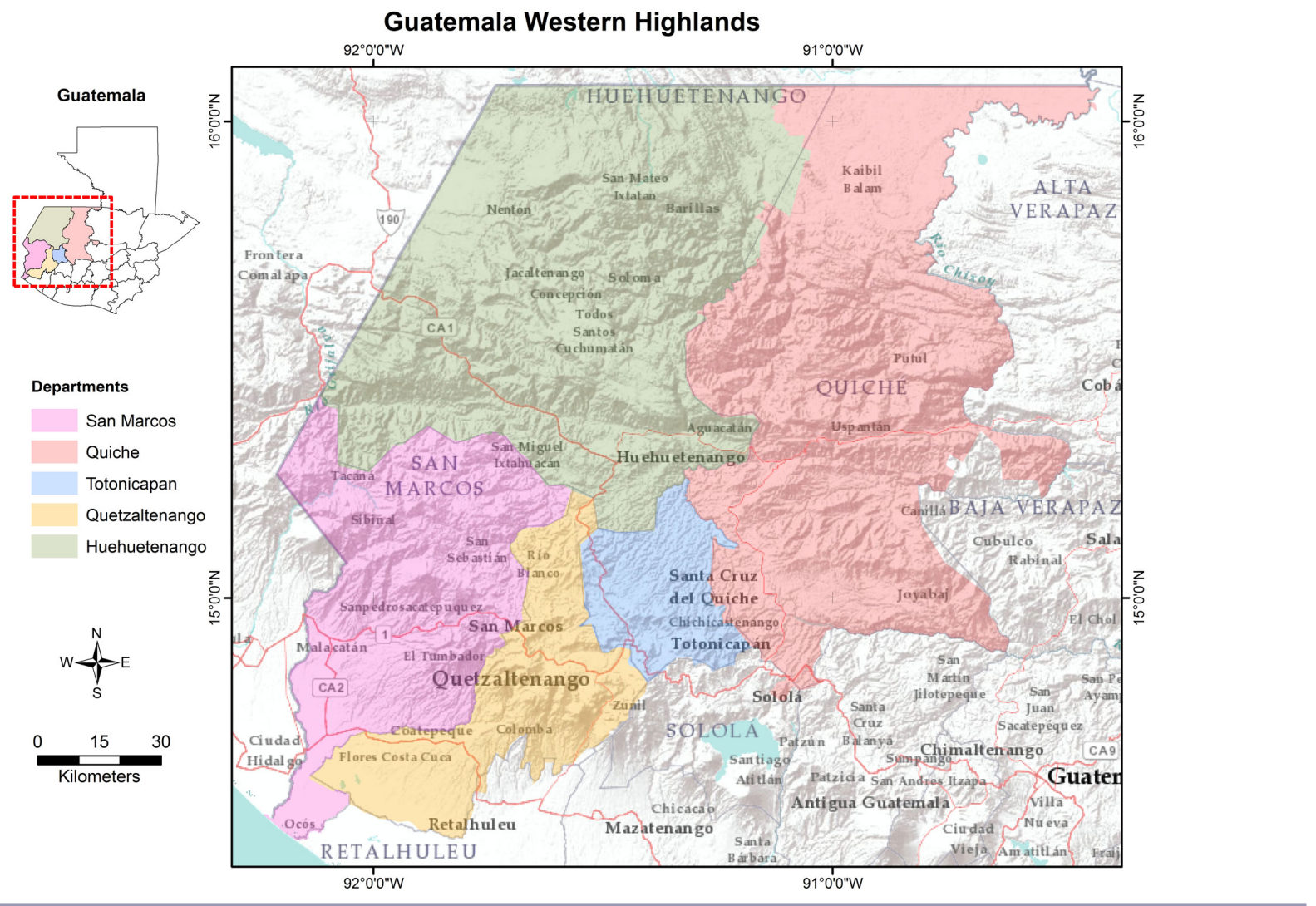

Maize is central to the food security of indigenous groups in the Western Highlands (van Etten 2006), and Guatemala has enormous maize diversity (Isakson 2009). Subsistence maize farming predominates in the Western Highlands, with cultivation being largely on deforested hill-slopes. For $70 \%$ of households, the main occupation of at least one household member is agriculture, and for $22 \%$ it is farm labor (Angeles et al. 2014). Recent research in the Western Highlands has shown that average land holding is 0.06 ha per person, an extremely low figure compared to other parts of Mesoamerica (Hellin et al. 2017). This contributes to considerable food insecurity: on average farm households produce enough maize (the main staple crop) for under seven months of consumption per year, and have to purchase maize from market sellers to make up the deficit; this has led to much migration by largely male farmers in the search for off-farm income as well as increased reliance on cash markets.

Following the U.S.-backed coup in 1954, the Guatemalan economy transformed with the growth of nontraditional export crops such as coffee, sugar, cotton, and beef (Grandin 1997). The Pan-American Highway, built in 1956-1957, was a key infrastructure project of the postcoup government (McAllister 2009). More recently, there has been an increase in smallholder farmer production of higher value vegetable crops for the export market and in some cases illicit poppy cultivation (Steinberg and Taylor 2007). The contribution of this export agriculture to wider poverty reduction has, however, been questioned (Krznaric 2006), not least because it often leads to a reduction in cultivation of maize (Steinberg and Taylor 2009), a loss of maize varieties, dependence on agrochemicals (Isakson 2014), and, in some cases, more food insecurity (Webb et al. 2016).

Population increase and subdivision of land has led to extreme land shortages in the Western Highlands (Steinberg and Taylor 2002) and a shortening of interannual fallow periods. This results in reduced soil fertility (Whittman and Johnson 2008) along with increased food insecurity (Mendoza et al. 2017). Deforestation leading to soil and land degradation has been going on for centuries (Hoy and Belisle 1984, Mathewson 2006) and exposes sloping lands to erosion and loss of soil fertility, hence, contributing to food insecurity. Furthermore, the World Bank (2011) has identified Guatemala as particularly vulnerable to climate change.

To cope with food insecurity and impoverishment associated with subsistence agriculture, many farmers, particularly men, are obliged to work off-farm. This involves part-time wage labor to make up shortfalls of staples and cash requirements for household goods, as well as to pay for inputs for the agricultural production process itself on their meagre landholdings. For able-bodied younger men, off-farm work includes migration to harvest coffee in Mexico or low wage (and often illegal) employment in the USA. Taylor et al. (2006) have conducted research in Guatemala on the impact of migrants' remittances on gender relations, ethnicity, land use, and land distribution. The influx of remittances has accelerated the conversion of forest into cattle pasture and the 
concentration of land in the hands of migrants and their families. The authors conclude that remittances are overwhelmingly used for personal benefit and that very little money is invested in ways that benefit neighbors or the community at large (Taylor et al. 2006, Steinberg and Taylor 2008). It may, hence, be the case that a reliance on remittances, while an essential coping strategy, discourages the type of community spirit and collective action that is often fundamental to increasing social-ecological resilience.

\section{Collective action institutions}

The three-decade-long armed conflict and its aftermath has had a huge influence on agricultural development in Guatemala, and on the challenge of fostering collective action and socialecological resistance. Deeply entrenched poverty, inequality, and poor law enforcement contribute to ongoing high levels of violence and a lamentable human rights situation especially for indigenous people in the highlands (Democracy International 2015). There are many parts of Guatemala where the legacy of the genocide during the conflict has left people "deeply suspicious of one another and profoundly divided over the concept of 'organisation"” (McAllister 2009:650). This poses a significant challenge to organizations seeking to work with communities for collective action and improved natural resource management.

There are, however, examples in which the shared experience of resistance to state repression also contributes to capacity for collective action. Wayland and Kuniholm (2016) argue that in some cases, the historical legacy of conflict has facilitated the mobilization of those opposed to potentially environmentally destructive projects such as mining of gold and silver. The authors conclude that "Indigenous communities experienced an increase in social cohesion as a result of the experience of conflict during la violencia that reinforced racial identity and facilitated subsequent collective action" (Wayland and Kuniholm 2016:402).

Van Leeuwen (2010) reports on the ability of civil society organizations (CSOs) to deal with agrarian conflict after the end of the military conflict in 1996. Van Leeuwen (2010) cautions that there are many political and ideological divisions among CSOs and little consensus on ways of mitigating agrarian conflict especially with respect to land distribution and tenure. The challenge has been that during the violent conflict, there was more of a consensus in opposing state repression, but that after the conflict ended, people and organizations differed on how to usher in needed social, political, and economic changes. Competition for donor funding and unscrupulous political parties have contributed to this situation (Van Leeuwen 2010) and in some cases stymies attempts to foster positive collective action.

Existing divisions are so profound that Guatemala has witnessed the situation whereby deeply traumatized indigenous peoples have voted for military leaders who were responsible for much of the genocide during the conflict (Copeland 2011). Some have partly attributed this phenomenon to the advancement of evangelical Christianity among indigenous groups; faiths espoused by former military leaders such as Ríos Montt who had a large following in the Western Highlands despite being responsible for some of the worst human rights violations during the conflict (Copeland 2011).

\section{Action arena}

Since the end of the conflict in 1996, the Guatemalan government and NGOs have focused development efforts on areas that suffered most during the violence (Taylor et al. 2006). For example, in the mid-1980s the government invested in extension services and credit for resource poor maize producers even though the initiative was scaled back in the early 1990s (Klepek 2012). During the 15 years after 2002, Guatemala has received US\$4.4 billion in bilateral official development assistance from all donors yet only $5.2 \%$ of this has gone to the agricultural sector (USAID 2017), despite the fact that the agriculture sector employs one in three Guatemalans (USAID 2017). In general development efforts directed at indigenous people have not received sufficient economic or political support to fulfill their potential(Democracy International 2015).

Following the end of the armed conflict, a World Bank supported market-led agrarian reform (MLAR) process started. Van Leeuwen (2010) reports that between 1997 and 2005, and as part of the reform process, government institutions were able to deal with only $1 \%$ of the total demand for land. Furthermore, much of this land was of poor quality (USAID 2017). In contrast, rural organizations have sought to acquire land through direct action and have been more successful than the MLAR process even though the amount of land allocated is so small that overall Guatemala's unequal land distribution continues largely unchanged (Granovsky-Larsen 2013). A report produced for USAID noted the following:

[T] he lack of a coherent system of land tenure and
property rights reinforces the continued concentration of
land ownership in the hands of a small but powerful elite;
it generates conflicts surrounding property rights,
boundaries, and illegal occupations, as well as renewed
land accumulation by new agricultural industries. This
fosters further disenfranchisement, reduces agricultural
productivity and economic viability of smallholders,
reinforces grievances, and foments greater poverty and
hunger, as well as greater conflict and social
fragmentation (Democracy International 2015:ii)

Despite the enormous challenges facing agricultural development in the Western Highlands, there is much potential. The Buena Milpa project has achieved much, largely because it has employed several experienced Guatemalan development professionals and through them has gained a sound understanding of the context of the Western Highlands. Buena Milpa has directed the majority of its resources at strengthening local organizations, e.g., ASOCUCH (see below) who have had a presence on the ground for many years and have established good relations with local communities. The approach used by Buena Milpa, therefore, illustrates that despite the legacy of the armed conflict in terms of debilitated CSOs, there are still opportunities for collective action. As Ratner et al. (2017) expound, much can be achieved by acquiring a sound understanding of the context of the region, the extant role of collective action institutions, and the varied actors engaged in the action arena. The following three case studies illustrate the advantages of bringing this knowledge together and aligning with grassroots and reputable organizations in order to influence the action arena. 


\section{CASE STUDIES OF INCREASING SOCIAL- ECOLOGICAL RESILIENCE}

\section{Collective action and the Pepajau microwatershed, Cuchumatanes, Western Highlands}

An influential NGO in the Western Highlands is La Asociación de Organizaciones de los Cuchumatanes (ASOCUCH; Association of Organizations of the Cuchumatanes). ASOCUCH has invested much in community-led natural resource management projects through strategic alliances with government actors and farmer groups and all this in an area that suffered much during the armed conflict. One of ASOCUCH's key partners is the Norwegian Development Fund (NDF). ASOCUH, NDF, and Buena Milpa are working with communities in designing and implementing climate change adaptation plans (Ortiz et al. 2015). The focus is the watershed level; working at this level encourages the collective management of natural resources such as forests, soils, and water in an integrated manner.

Eakin and Lemos (2006) posit that the high uncertainties in climate change scenarios mean that it may be more sensible to improve adaptive capacity rather than the promotion of specific climate adaptation options per se. As Thornton et al. (2009) write, in place of defining large development domains for identifying and implementing adaptation options, there is a need for localized, community-based efforts to increase local adaptive capacity. ASOCUCH's long-term presence and establishment of trust with communities has contributed to enhanced adaptation capacity and a sound foundation for favorably influencing the action arena, an approach that guided intervention in watershed management in Todos Santos (see below).

During the first step, the community analyzes the extent of climate vulnerability making use of participatory tools. During the process, the community learns about the current and potential effects of climate change and its impact on the local economy. The analytical phase includes both traditional knowledge and available technical and scientific information. At the end of the vulnerability analysis, the community members know the main climatic challenges, and define the options to implement adaptation and mitigation actions. Information gathered in the vulnerability analysis is the basis for preparation of the adaptation plan. The plan defines activities, a budget, and an adaptation committee made up of community leaders, who are responsible for ensuring compliance with the activities.

NDF provides financing directly to the community. Financial resources are used both for investments in collective action such as the management of common property resources, as well as for micro credit schemes geared at individual households. There is also an association or cooperative of producers legally constituted, which is in charge of managing the funds. The provision of credit contributes to the sustainability of the communities' adaptation plan. Those who receive the credit, make a commitment to implement soil conservation practices, planting forest and fruit trees, and maintain crop diversity while being able to pursue individual productive and commercial activities.

ASOCUCH invested considerable time and effort in fostering collective action in an area where there were deep social divisions and tensions. The approach has led to impressive farmer implementation and maintenance of climate change adaptation measures. This compares favorably to other experiences in the region where farmer adoption of such technologies has been limited. Ortiz et al (2015) report on some of the achievements that include the following:

1. Construction of a community seed reserve, which allows farmers to safeguard mainly maize and bean seeds for food security.

2. Establishment and management of a clonal potato garden with 40 potato varieties, in order to recover the native agrobiodiversity.

3. Establishment of 18,600 meters of cross-slope soil conservation in maize and potato growing areas, surpassing the initial goal of the project for the first two years.

4. Management of a credit portfolio of US $\$ 16,000$, benefiting 100 families with the provision of agricultural and livestock credit.

5. Expansion of the local road, a critical step to enhancing market access.

6. Production of 30,000 plants for reforestation of local species

7. Community involvement in the Programa de incentivos para poseedores de pequeñas extensiones de tierras de vocación forestal o agroforestal (PINPEP; Forest Incentives Program for small holders with forestry or agroforestry plots) whereby the government pays landowners to plant trees and manage forests. The communities are protecting almost 400 hectares of forest and have reforested a further 25 hectares.

Collective action to protect natural resources in Todos Santos, Cuchumatanes, Western Highlands

Buena Milpa has recently supported a similar but longer-standing watershed management endeavor in the municipality of Todos Santos, Cuchumatanes, in the department of Huehuetenango. Todos Santos witnessed some of the worst atrocities of the armed conflict and this led to deep social and political divisions throughout the municipality. After the end of the conflict and with support from international donors, the Fundación para el Ecodesarrollo y la Conservación (FUNDAECO), in collaboration with several partners, began a participatory process to delimit and declare a protected area in order to halt natural resource degradation in Todos Santos. The long-term endeavor included awareness raising among authorities and inhabitants of the communities, capacity building on administrative and technical aspects of natural resource conservation, and eventually the declaration of the protected reserve.

The communities were involved in participatory assessments of areas with the highest ecological value along with the identification of sacred or ceremonial sites and areas with potential for economic activities based on ecotourism. Much of the land identified as requiring protection was on municipal land but community managed. In July 2002, the municipal authorities acknowledged the need to protect the area and started a long consultative process with the communities, represented by five grassroots farmer organizations.

FUNDAECO organized field visits with the municipal authorities and representatives from the farmer organizations. Through negotiations, the stakeholders agreed on a municipal 
reserve of 7225 hectares that included 68 communities within the Todos Santos municipality. The process involved more than 100 workshops not only to reach agreement on the size of the reserve but also to build local capacity around the basic elements of management of protected areas, and the legal aspects related to protected areas and environmental legislation. Capacity building included the technical aspects of resource protection, natural forest regeneration, reforestation, soil and water conservation, and potato and vegetable production. More than 1500 people from the 68 communities received training on these topics.

A commission of natural resource management was established in each of the 68 communities and these were integrated into an overarching organization, Coordinadora de Comisiones de Recursos Naturales (COCOREMA). Members of the COCOREMA are responsible for developing an annual plan for the management of the natural reserve and presented it to the municipal authorities as well as the rest of the 68 commissions for their approval. COCOREMA has played a crucial role in the mediation and communication between local traditional authorities and municipal authorities.

In June 2004, and after more than four years' work by FUNDAECO and partners, the National Council of Protected Areas (Consejo Nacional de Areas Protegidas, or CONAP) officially recognized the reserve and included it in the official registry (Sistema Guatemalteco de Areas Protegidas, or SIGAP). The declaration of the reserve and the implementation of the management plan yielded multiple advantages to the communities involved in the forest reserve. Communities received financial incentives for their sustainable management of the forest and their engagement in productive projects related to sheep management, soil and water conservation, and harvesting of nontimber forest products.

Further cooperation among the 68 communities and municipal authorities led to greater recognition of the reserve's importance in terms of cultural heritage, unique scenery, and potential for outdoor activities and tourism. In 2010, the reserve was granted the status of Municipal Regional Park with the name of "K'ojlab'1 Tze' Te Tnom Todos Santos Cuchumatán." This new status maintains a focus on the conservation of resources but allows for environmental education and recreational activities such as hiking (Municipalidad de Todos Santos Cuchumatán 2016). The master management plan of the regional park is updated every five years and it is based on an analysis, in close consultation with stakeholders, of the strengths and weaknesses of the park and the identification of main threats and opportunities. Success in the action arena was based on FUNDAECO's long-term plan and its painstaking engagement with the communities, municipal authorities, and local farmer organizations in order to reach consensus on the need for and management of the reserve. The success has built upon a deep understanding of local dynamics and a long-term presence on the ground that allows for the building of trust and cooperation, factors that are key as well in the next example of the management of maize varieties.

\section{Maize seed, climate change adaptation, and social-ecological resilience}

Maize is central to indigenous peoples' culture and livelihoods. Generations of selection by farmers under local conditions has led to local maize varieties with resistance to drought, heat, local pests, and diseases (CIMMYT 2017). Most small-scale maize farmers in Guatemala recycle seed. They either save it from the previous harvest and/or obtain it from fellow farmers. Seed sourcing is embedded in well-structured traditional systems that are governed by rules and expectations based on family and local social networks, and the ideas of fairness (Isakson 2009, Bellon et al. 2011). Maize cultivation has contributed to cementing community membership, although Steinberg and Taylor (2002) suggest that farmers grow fewer maize varieties than in the past and that this decline is in part due to the civil war that disrupted both farming practices and community institutions.

Climate models suggest that climate change will have major impacts on small-scale farmers in Guatemala whose livelihoods depend on rain-fed maize (Hellin et al. 2017). Traditional maize seed systems in Guatemala may be able to provide small-scale farmers with appropriate genetic material, i.e., there may already be existing crop germplasm in the form of farmers' local maize varieties that is appropriate for predicted climates (Mercer et al. 2012). Furthermore, landrace populations may also be able to "keep up" with climate change because of farmer selection of climate-adapted traits among landraces (Mercer and Perales 2010).

During the conflict, many farmers fled to refugee camps in neighboring Mexico and those who did remain dramatically curtailed their farming activities for fear of the army (Steinberg and Taylor 2002). Furthermore, growing maize has potent symbolic, spiritual, and cultural value in the Mayan-Catholic syncretic faith (Tyndale 2006); the conversion of increasing numbers of indigenous households to evangelical denominations also contributed to a decline in traditional maize cultivation (Steinberg and Taylor 2002, Isakson 2014).

The loss of local maize varieties is serious because an alternative approach whereby farmers rely on climate-adapted maize germplasm arising from formal crop breeding programs is less attractive. First, scientific breeding programs have seldom developed varieties suitable to the marginal agroecological conditions that smallholder farmers often face because conditions are so heterogeneous that it makes breeding for a myriad of agroecological zones prohibitive. Second, even if such germplasm existed, farmers do not have the financial resources to purchase the seed. Third, formal seed systems are not in place to facilitate farmers' access to seed. This suggests that the most promising approach for adapting these systems to climate change is to rely on local maize varieties available to farmers (Bellon et al. 2011). Based on an analysis of the context and working with local organizations, the Buena Milpa project has embarked on a multipronged approach to conserve and enhance maize diversity in the Western Highlands.

In the 1950s, and with the support of the Guatemalan Ministry of Agriculture Livestock and Food (MAGA), scientists carried out an extensive collection of maize varieties in Guatemala including the Western Highlands. Eventually the collection was stored in the Germplasm Bank at the International Maize and Wheat Improvement Center (CIMMYT) in Mexico. Some of the seed collected was also stored at Guatemala's national seed bank. The entire maize seed collection at Guatemala's national seed bank was damaged by humid conditions and became vulnerable 
to insects and fungus. The stored seed could not be used as part of efforts to reintroduce traditional maize varieties to areas from where they had been lost.

In 2016 and after almost 70 years in storage, scientists at CIMMYT have repatriated some of the maize germplasm to Guatemala. This comprised seed of more than 700 native Guatemalan maize varieties, including some of the varieties that had been lost during the last two to three decades (CIMMYT 2017). Local farmers can now evaluate the repatriated germplasm in terms of its resistance to pests and diseases, nutritional quality, and suitability to changing climatic conditions. Guatemalan scientists are now planting seed from the historic CIMMYT samples and they will return the best varieties to local and national seedbanks in Guatemala, where they will be available for farmers and researchers to grow. The Buena Milpa project is also working with smallholder farmers to improve storage practices in community seed reserves, tiny, low-tech seed banks that serve as backup for villages in cases of catastrophic seed loss (CIMMYT 2017). Along with the investment in research, the approach requires a revitalization of community institutions for managing and distributing the seed varieties.

\section{DISCUSSION}

Improving cooperation in the management of renewable, common-pool resources is an important element in building social-ecological resilience. The challenge is particularly acute in the Western Highlands. The three case studies reported here demonstrate how grassroots approaches to collective action have provided opportunities to foster community-level climate adaptation strategies despite long-running social, economic, and political divisions. The conceptual framework on resource conflict, collective action, and social-ecological resilience that Ratner et al. (2013) developed, informed Buena Milpa's approach in Guatemala.

Ratner et al. (2017) argue the need to understand the governance context of the region, the role of collective action institutions, and the scope of influence for the varied actors engaged in the more immediate action arena in which decisions affecting resource management are made. This approach influenced Buena Milpa from the design to implementation phases. Staff with a sound knowledge of the social, economic, and political context in Guatemala designed the project. This included an understanding of the impact of the three-decade-long armed conflict on trust and cooperation within largely indigenous communities and in the relationship between these communities and outsiders. Buena Milpa has directed the majority of its resources at strengthening local organizations who have had a presence on the ground for many years and have established good relations with local communities. The three case studies illustrate the advantages of bringing this knowledge together and aligning with grassroots and reputable organizations in order to influence the action arena.

In the case of the Pepajau microwatershed, Buena Milpa has worked with and supported ASOCUCH, a local NGO with a well-established presence and grassroots legitimacy in the local area. In Todos Santos, Buena Milpa has worked with FUNDAECO, an organization with a strong presence on the ground and with links to the wider political stage. This profile, along with the extended investment in dialogue and negotiation processes at multiple levels, largely accounts for the success in national recognition of the reserve as a protected area and Municipal Regional Park. In the case of the reintroduction of maize seed, Buena Milpa built on previous efforts to conserve the diversity of maize in the region. The project worked with Guatemalan maize experts and local communities to identify local areas where maize diversity had been lost because of the armed conflict and where suitable ex-situ maize germplasm existed for repatriation. These efforts have been complemented by community-level collective action directed at the establishment of community seed reserves, which combines a revitalization of traditional practices with significant institutional innovation.

All three examples contribute to social-ecological resilience by enhancing communities' adaptation to climate change. Improved natural resource management and the conservation and use of local maize varieties reduces farmers' vulnerability to drought, and pest and diseases. The watershed management efforts have led to increased food security and greater income generation and employment opportunities via access to markets and ecotourism linked to conservation efforts. Although there is still much to do, the examples demonstrate what can be achieved in conflictaffected areas through the fostering of collective action that links food production, natural resource management, and community livelihoods.

\section{CONCLUSION}

Climate change is a threat to agriculture and food security. Climate change adaptation and mitigation strategies have focused primarily on the development of agricultural technologies and practices. There are growing concerns, however, that climate change will undermine agricultural development efforts, exacerbate conflict, and ultimately threaten human security and undermine social stability. Researchers and policy makers, therefore, need to direct more attention toward approaches to transform resource competition to strengthen social-ecological resilience, enhance local adaptation capacity, and mitigate conflict risk.

Efforts to enhance collective action can also foster the emergence of cooperation around the management of natural resources. This can reduce the likelihood of conflict over access to and use of these resources, and ultimately contribute to greater socialecological resilience. The three case studies in Guatemala illustrate how practical efforts to support social-ecological resilience can emerge after several decades of armed conflict that was not only caused by deep social, economic, and political divisions but also exacerbated many of these divisions. Guided by a conceptual framework on resource conflict, collective action, and social-ecological resilience, we illustrate how a deep understanding of the context of conflict in agriculture, together with the fostering of collective action institutions, can lead to changes in the action arena that help foster greater socialecological resilience.

The Buena Milpa case studies suggest that nurturing the reemergence of this resilience among poor and marginalized groups requires the brokering role of reputable and trusted local organizations able to navigate a challenging governance environment. The project actively sought out and supported these organizations, and worked to identify ways to support their efforts with scientific expertise, financial resources, and capacity building 
to advance social-ecological resilience among communities reliant upon maize cultivation. It was essential that this be done in a way that enhanced the capabilities of these local organizations without undermining their legitimacy in the eyes of either community or government actors.

The examples from the Western Highlands of Guatemala, however, do not suggest that the process is easy. Although watershed management, re-establishment of traditional maize varieties, and strengthening of local institutions for managing agro-biodiversity are important elements of increasing resilience in these highland communities, there is no doubt that many other social, technological, and institutional dimensions of adaptation are important as well. Moreover, there remain many parts of the region where the social fabric is so eroded that the odds are severely stacked against efforts to rebuild collective institutions for natural resource management. This sobering realization highlights the substantial investments in peace-building that sometimes must accompany efforts to foster collective action and contribute to greater resilience in agricultural systems and livelihoods.

Responses to this article can be read online at: http://www.ecologyandsociety.org/issues/responses. $\mathrm{php} / 10250$

\begin{abstract}
Acknowledgments:
We would like to acknowledge support provided by United States Agency for International Development (USAID) through its Global Hunger and Food Security Initiative, Feed the Future. This work was also implemented as part of the CGIAR Research Program on Climate Change, Agriculture and Food Security (CCAFS), which is carried out with support from CGIAR Fund Donors and through bilateral funding agreements (for details please visit https:/lccafs.cgiar.org/donors\#.WxqT 4onaUk), and the CGIAR Research Programs on Policies, Institutions and Markets (PIM). The views expressed in this document cannot be taken to reflect the official opinions of these organizations. The authors are also very grateful for the invaluable comments provided by two anonymous reviewers and Eleanor Fisher (University of Reading, $U K)$.
\end{abstract}

\section{LITERATURE CITED}

Adger, W. N. 2003. Social capital, collective action, and adaptation to climate change. Economic Geography 79 (4):387-404. http://dx.doi.org/10.1111/j.1944-8287.2003.tb00220. $\underline{\mathrm{x}}$

Adger, W. N., J. Barnett, K. Brown, N. Marshall, and K. O’Brien. 2013. Cultural dimensions of climate change impacts and adaptation. Nature Climate Change 3(2):112-117. http://dx.doi. org/10.1038/nclimate1666

Angeles, G., E. Hidalgo, R. Molina-Cruz, T. Taylor, J. UrquietaSalomón, C. Calderón, J. C. Fernández, M. Hidalgo, K. Brugh, and M. Romero. 2014. Encuesta de Monitoreo y Evaluación del Programa del Altiplano Occidental, Línea de Base 2013. USAID, Washington, D.C., USA. [online] URL: https://www. measureevaluation.org/resources/publications/tr-14-100-es
Barnett, J., and W. N. Adger. 2007. Climate change, human security and violent conflict. Political Geography 26(6):639-655. http://dx.doi.org/10.1016/j.polgeo.2007.03.003

Barrett, C. B., and M. A. Constas. 2014. Toward a theory of resilience for international development applications. Proceedings of the National Academy of Sciences of the United States of America 111(40):14625-14630. http://dx.doi.org/10.1073/pnas.1320880111

Bellon, M. R., D. Hodson, and J. Hellin. 2011. Assessing the vulnerability of traditional maize seed systems in Mexico to climate change. Proceedings of the National Academy of Sciences of the United States of America 108(33):13432-13437. http://dx. doi.org/10.1073/pnas. 1103373108

Brown, M. E., and C. C. Funk. 2008. Food security under climate change. Science 319(5863):580-581. http://dx.doi.org/10.1126/ science. 1154102

CIMMYT (International Maize and Wheat Improvement Center). 2017. Maize and wheat for future climates: CIMMYT Annual Report 2016. CIMMYT, Mexico City, Mexico.

Copeland, N. 2011. 'Guatemala will never change': radical pessimism and the politics of personal interest in the Western Highlands. Journal of Latin American Studies 43:485-515. http:// dx.doi.org/10.1017/S0022216X11000411

Democracy International. 2015. Legacies of exclusion: social conflict and violence in communities and Homes in Guatemala's Western Highlands. Democracy International, Bethesda, Maryland, USA.

Eakin, H., and M. C. Lemos. 2006. Adaptation and the state: Latin America and the challenge of capacity-building under globalization. Global Environmental Change 16:7-18. http://dx. doi.org/10.1016/j.gloenvcha.2005.10.004

Gleditsch, N. P., K. Furlong, H. Hegre, B. Lacina, and T. Owen. 2006. Conflicts over shared rivers: resource scarcity or fuzzy boundaries? Political Geography 25(4):361-382. http://dx.doi. org/10.1016/j.polgeo.2006.02.004

Grandin, G. 1997. To end with all these evils: ethnic transformation and community mobilization in Guatemala's Western Highlands, 1954-1980. Latin American Perspectives 24 (2):7-34. http://dx.doi.org/10.1177/0094582X9702400202

Granovsky-Larsen, S. 2013. Between the bullet and the bank: agrarian conflict and access to land in neoliberal Guatemala. Journal of Peasant Studies 40(2):325-350. http://dx.doi. org/10.1080/03066150.2013.777044

Hanjra, M. A., and M. E. Qureshi. 2010. Global water crisis and future food security in an era of climate change. Food Policy 35 (5):365-377. http://dx.doi.org/10.1016/j.foodpol.2010.05.006

Hellin, J., R. Cox, and S. López-Ridaura. 2017. Maize diversity, market access, and poverty reduction in the Western Highlands of Guatemala. Mountain Research and Development 37 (2):188-197. http://dx.doi.org/10.1659/MRD-JOURNAL-D-16-00065.1

Hellin, J., and S. Lopez-Ridaura. 2016. Soil and water conservation on Central American hillsides: if more technologies is the answer, what is the question? AIMS Agriculture and Food 1 (2):194-207. http://dx.doi.org/10.3934/agrfood.2016.2.194 
Hendrix, C. S., and S. M. Glaser. 2007. Trends and triggers: climate, climate change and civil conflict in Sub-Saharan Africa. Political Geography 26(6):695-715. http://dx.doi.org/10.1016/j. polgeo.2007.06.006

Higbee, E. C. 1947. The agricultural regions of Guatemala. American Geographical Society 37(2):177-201. http://dx.doi. org/10.2307/210767

Hoy, D., and F. Belisle. 1984. Environmental protection and economic development in Guatemala's Western Highlands. Journal of Developing Areas 18(2):161-176.

Institute of Development Studies. 2010. Change and conflict moving beyond the impasse. Institute of Development Studies, Brighton, UK.

International Fund for Agricultural Development. 2011. Enabling poor rural people to overcome poverty in Guatemala. International Fund for Agricultural Development, Rome, Italy. [online] URL: https://www.ifad.org/documents/10180/16e68b93-2e7f-4804-8385-b8d53d784130

Isakson, S. R. 2009. No hay ganancia en la milpa: the agrarian question, food sovereignty, and the on-farm conservation of agrobiodiversity in the Guatemalan Highlands. Journal of Peasant Studies 36(4):725-759. http://dx.doi.org/10.1080/030661$\underline{50903353876}$

Isakson, S. R. 2014. Maize diversity and the political economy of agrarian restructuring in Guatemala. Journal of Agrarian Change 14(3):347-379. http://dx.doi.org/10.1111/joac.12023

Klepek, J. 2012. Selling Guatemala's next Green Revolution: agricultural modernization and the politics of GM maize regulation. International Journal of Agricultural Sustainability 10 (2):117-134. http://dx.doi.org/10.1080/14735903.2012.641326

Krznaric, R. 2006. The limits on pro-poor agricultural trade in Guatemala: land, labour and political power. Journal of Human Development 7(1):111-135. http://dx.doi.org/10.1080/14649880500502144

Lobell, D. B., M. B. Burke, C. Tebaldi, M. D. Mastrandrea, W. P. Falcon, R. L. Naylor. 2008. Prioritizing climate change adaptation needs for food security in 2030. Science 319 (5863):607-610. http://dx.doi.org/10.1126/science.1152339

Lovell, W. G. 1983. To submit and to serve: forced native labour in the Cuchumatán Highlands of Guatemala, 1525-1821. Journal of Historical Geography 9(2):127-144. http://dx.doi.org/10.1016/0305-7488 (83)90219-0

Mathewson, K. 2006. A century and counting: geographical research on Guatemala in historical perspective. Geoforum 37 (1):15-30. http://dx.doi.org/10.1016/j.geoforum.2005.01.009

McAllister, C. 2009. Seeing like an indigenous community: the World Bank's Agriculture for Development Report read from the perspective of postwar rural Guatemala. Journal of Peasant Studies 36(3):645-651. http://dx.doi.org/10.1080/03066150903143038

Mendoza, J. R., L. Sabillón, W. Martinez, C. Campabadal, H. E. Hallen-Adams, and A. Bianchini. 2017. Traditional maize postharvest management practices amongst smallholder farmers in Guatemala. Journal of Stored Products Research 71:14-21. http:// dx.doi.org/10.1016/j.jspr.2016.12.007
Mercer, K. L., and H. R. Perales. 2010. Evolutionary response of landraces to climate change in centers of crop diversity. Evolutionary Applications 3(5-6):480-493. http://dx.doi.org/10.1111/ j.1752-4571.2010.00137.X

Mercer, K. L., H. R. Perales, and J. D. Wainwright. 2012. Climate change and the transgenic adaptation strategy: smallholder livelihoods, climate justice, and maize landraces in Mexico. Global Environmental Change 22(2):495-504. http://dx.doi.org/10.1016/ j.gloenvcha. 2012.01.003

Municipalidad de Todos Santos Cuchumatán. 2016. Plan Maestro: Parque Regional Municipal "K'OJLAB'L TZE'TE TNOM" Todos Santos Cuchumatán. Documento técnico No. 06-2016. Consejo Nacional de Áreas Protegidas, Guatemala City, Guatemala. [online] URL: http://168.234.196.99/Documentos/ SIGAP/PMR/PM\%20PRM\%20Todo\%20Santos.pdf

Ortiz, R., S. Alonzo, J. Hellin, and R. Cox. 2015. Comunidades adaptadas al cambio climático, un modelo de adaptación local exitoso en la conservación de los suelos, los bosques y los materiales genéticos. Enlace 28:42-46.

Ostrom, E. 2005. Understanding institutional diversity. Princeton University Press, Princeton, New Jersey, USA.

Ratner, B. D., R. Meinzen-Dick, J. Hellin, E. Mapedza, J. Unruh, W. Veening, E. Haglund, C. May, and C. Bruch. 2017. Addressing conflict through collective action in natural resource management. International Journal of the Commons 11 (2):877-906. http://dx.doi.org/10.18352/ijc.768

Ratner, B. D., R. Meinzen-Dick, C. May, and E. Haglund. 2013. Resource conflict, collective action, and resilience: an analytical framework. International Journal of the Commons 7(1):183-208. http://dx.doi.org/10.18352/ijc. 276

Scheffran, J., M. Brzoska, J. Kominek, P. M. Link, and J. Schilling. 2012. Climate change and violent conflict. Science 336 (6083):869-871. http://dx.doi.org/10.1126/science.1221339

Steinberg, M. K., and M. Taylor. 2002. The impact of political turmoil on maize culture and diversity in Highland Guatemala. Mountain Research and Development 22(4):344-351. http://dx.doi. org/10.1659/0276-4741(2002)022[0344:TIOPTO]2.0.CO;2

Steinberg, M. K., and M. Taylor. 2007. Marginalizing a vulnerable cultural and environmental landscape. Mountain Research and Development 27(4):318-321. http://dx.doi.org/10.1659/mrd.0948

Steinberg, M., and M. Taylor. 2008. Guatemala's Altos de Chiantla: changes on the high frontier. Mountain Research and Development 28(3):255-262. http://dx.doi.org/10.1659/mrd.0891

Steinberg, M. K., and M. J. Taylor. 2009. The direct and indirect impacts of population growth and economic development on maize (Zea mays L.) diversity in highland Guatemala. Area 41 (1):72-81. http://dx.doi.org/10.1111/j.1475-4762.2008.00850.x

Taylor, M. J., M. J. Moran-Taylor, and D. Rodman Ruiz. 2006. Land, ethnic, and gender change: transnational migration and its effects on Guatemalan lives and landscapes. Geoforum 37 (1):41-61. http://dx.doi.org/10.1016/j.geoforum.2004.12.002

Thornton, P. K., P. G. Jones, G. Alagarswamy, and J. Andresen. 2009. Spatial variation of crop yield response to climate change 
in East Africa. Global Environmental Change 19(1):54-65. http:// dx.doi.org/10.1016/j.gloenvcha.2008.08.005

Tyndale, W. 2006. Mayan and Catholic spiritual traditions. Mountain Research and Development 26(4):315-318. http://dx.doi. org/10.1659/0276-4741(2006)26[315:MACST]2.0.CO;2

United States Agency for International Development (USAID). 2017. Analytical brief. Economic analysis and data service team. USAID, Washington, D.C., USA.

van Etten, J. 2006. Molding maize: the shaping of a crop diversity landscape in the Western Highlands of Guatemala. Journal of Historical Geography 32(4):689-711. http://dx.doi.org/10.1016/j. jhg.2005.12.002

Van Leeuwen, M. 2010. To conform or to confront? CSOs and agrarian conflict in post-conflict Guatemala. Journal of Latin American Studies 42(1):91-119. http://dx.doi.org/10.1017/ $\underline{\mathrm{S} 0022216 \mathrm{X} 10000064}$

Vermeulen, S. J., A. J. Challinor, P. K. Thornton, B. M. Campbell, N. Eriyagama, J. M. Vervoort, J. Kinyangi, A. Jarvis, P. Läderach, J. Ramirez-Villegas, K. J. Nicklin, E. Hawkins, and D. R. Smith. 2013. Addressing uncertainty in adaptation planning for agriculture. Proceedings of the National Academy of Sciences of the United States of America 110(21):8357-8362. http://dx.doi. org/10.1073/pnas. 1219441110

Walker, B., C. S. Holling, S Carpenter, and A. Kinzig. 2004. Resilience, adaptability and transformability in social-ecological systems. Ecology and Society 9(2):5. http://dx.doi.org/10.5751/ ES-00650-090205

Wayland, J., and M. Kuniholm. 2016. Legacies of conflict and natural resource resistance in Guatemala. Extractive Industries and Society 3(2):395-403. http://dx.doi.org/10.1016/j.exis.2016.03.001

Webb, M. F., A. N. Chary, T. T. De Vries, S. Davis, M. Dykstra, D. Flood, M. H. Rhodes, and P. Rohloff. 2016. Exploring mechanisms of food insecurity in indigenous agricultural communities in Guatemala: a mixed methods study. $B M C$ Nutrition 2(1):55. http://dx.doi.org/10.1186/s40795-016-0091-5

Whittman, H. K., and M. S. Johnson. 2008. Fallow management practices in Guatemala's Western Highlands: social drivers and biophysical impacts. Land Degradation and Development 19:178-189. http://dx.doi.org/10.1002/ldr.832

World Bank. 2011. Vulnerability, risk reduction, and adaptation to climate change: Guatemala. World Bank, Washington, D.C., USA. [online] URL: http://sdwebx.worldbank.org/climateportalb/ doc/GFDRRCountryProfiles/wb gfdrr_climate_change country profile for GTM.pdf

World Food Programme. 2014. Guatemala. World Food Programme, Rome, Italy. [online] URL: http://www1.wfp.org/ countries/guatemala 